\title{
Upaya Meningkatkan Hasil Belajar Lompat Jauh Gaya Jongkok Melalui Penggunaan Media Alat Bantu Box bagi Siswa SDN 38 Ampenan
}

\author{
Magdalena \\ SD Negeri 38 Ampenan, Kota Mataram \\ Corresponding Author. Email: magdalena@gmail.com
}

\begin{abstract}
This study aims to improve learning outcomes squat-style long jump through the use of the media as a tool for students at SD Negeri 38 Ampenan. This research method uses classroom action research methods with research subjects namely fifth grade students of SD Negeri 38 Ampenan. The research instrument used observation, interviews, and tests. The data analysis technique used in this research was qualitative and quantitative descriptive analysis. The results of this study indicate that learning the long jump squat style through the use of assistive media can increase student focus and activeness as well as a pleasant learning atmosphere which has an impact on improving student learning outcomes.
\end{abstract}

\begin{abstract}
Abstrak: Penelitian ini bertujuan untuk meningkatkan hasil belajar lompat jauh gaya jongkok melalui penggunaan media alat bantu Box bagi siswa di SD Negeri 38 Ampenan. Metode penelitian ini menggunakan metode penelitian tindakan kelas dengan subjek penelitian yakni siswa kelas V SD Negeri 38 Ampenan. Instrumen penelitian ini menggunakan observasi, wawancara, dan tes. Teknik analisis data penelitian ini menggunakan analisis deskriptif kualitatif dan kuantitatif. Hasil penelitian ini menunjukkan bahwa pembelajaran lompat jauh gaya jongkok melalui penggunaan media alat bantu dapat meningkatkan fokus dan keaktifan siswa serta suasana pembelajaran yang menyenangkan yang berdampak pada peningkatan hasil belajar siswa.
\end{abstract}

Key Words:

Learning Outcomes,

Long Jump, Box Media.

Kata Kunci:

Hasil Belajar, Lompat

Jauh, Media Box.

How to Cite: Magdalena, M. (2020). Upaya Meningkatkan Hasil Belajar Lompat Jauh Gaya Jongkok Melalui Penggunaan Media Alat Bantu Box bagi Siswa SDN 38 Ampenan. Jurnal Teknologi Pendidikan, 5(2), 167-173. Retrieved from http://ojs.ikipmataram.ac.id/index.php/jtp/article/view/3061

\section{Pendahuluan}

Pendidikan jasmani pada dasarnya merupakan bagian integral dari sistem pendidikan secara keseluruhan yang bertujuan untuk mengembangkan aspek kesehatan. Pendidikan jasmani merupakan alat untuk mencapai pendidikan jasmani dan olah raga di sekolah sebelum mendapatkan format yang tepat, karena selalu menyesuaikan perubahan kurikulum. Pada kurikulum KBK (Kurikulum Bebasis Kompetensi) diharapkan dapat menggali potensi yang ada untuk dikembangkan, belum bisa dilihat hasilnya dari kurikulum KBK. Ada bentuk kurikulum baru yang disebut KTSP (Kurikulum Tingkat Satuan Pendidikan) yang sekarang sedang dilaksanakan.

Proses pembelajaran pendidikan jasmani, olah raga, dan kesehatan di sekolah dasar mengutamakan kesehatan mental dan kesegaran jasmani, untuk mencari calon atlet harus benar-benar sesuai dengan cabangnya. Keadaan siswa SD Negeri 38 Ampenan pada dasarnya senang terhadap pembelajaran pendidikan jasmani dan olah raga, terutama pada cabang permainan. Pada cabang atletik, anak kurang menyenangi dengan alasan tidak menyenangkan. Karena pembelajaran atletik di SD Negeri 38 Ampenan kurang mendapat tanggapan yang positif dari para siswa, maka prestasi pada cabang atletik khusus pada nomor lompat jauh belum bisa optimal. Hal ini bisa terjadi karena beberapa faktor penyebab, yaitu: 
(1) Terbatasnya kemampuan guru pendidikan jasmani, dan (2) Terbatasnya alat bantu dalam proses pembelajaran pendidikan jasmani.

Terbatasnya kemampuan guru pendidikan jasmani di SD akan berakibat pada proses pembelajaran yang kurang berhasil. Karena guru kurang mampu dalam melaksanakan profesinya secara profesional, dan kurang berhasil dalam mengajar dan mendidik siswa secara sistematik. Karena dalam pembelajaran pendidikan jasmani diberikan gerakan yang sistematik untuk mengembangkan kemampuan dan keterampilan siswa secara menyeluruh baik fisik, mental, maupun intelektual.

Gaya yang dipakai guru dalam mengajar praktek pendidikan jasmani juga monoton, yaitu hanya menggunakan satu gaya mengajar. Sehingga situasi pembelajaran yang dirasakan oleh siswa terasa membosankan. Dan juga metode praktik ditekankan pada latihan-latihan berdasarkan perintah yang ditentukan oleh guru. Latihan-latihan tersebut tidak dilakukan sesuai inisiatif dari siswa itu sendiri. Dalam hal ini guru cenderung menggunakan pendekatan pembelajaran yang mengarah pada prestasi. Sehingga dalam prosesnya berbeda dari pembelajaran penjas itu sendiri, yaitu tujuan utama bukan proses dalam peraturan, ukuran lapangan, maupun alat. Proses pembelajaran seperti ini akan membuat siswa kurang senang untuk melaksanakannya, bahkan merasa bosan dan yang lebih fatal siswa merasa frustasi untuk melaksanakan tugas dari guru.

Pembelajaran di SD Negeri 38 Ampenan siswa kelas V tersebut mengalami kesulitan dalam melakukan tehnik lompat jauh gaya jongkok. Sebagian besar siswa baru menguasai cara melompat. Mereka belum mampu melakukan gerakan secara keseluruhan terbukti dari hasil evaluasi, dari siswa kelas $\mathrm{V}$ yang berjumlah 15 anak yang terdiri dari 10 siswa laki-laki dan 5 siswa perempuan, baru 5 siswa $(33,3 \%)$ yang dapat melakukan teknik lompat jauh gaya jongkok dan sisanya masih 10 siswa $(66,7 \%)$ yang masih belum menguasai teknik lompat jauh gaya jongkok.

Dengan keadaan seperti ini tentu dibutuhkan penggunaan alat bantu pembelajaran sebagai suatu pendekatan alternatif dalam mengajaran pendidikan jasmani. Guru harus mempunyai kemampuan untuk memodifikasi keterampilan yang hendak diajarkan dengan harapan sesuai dengan tingkat kemampuan dan perkembangan siswa. Dalam hal ini guru harus kreatif, inovatif dalam menciptakan proses pembelajaran bagi siswa. Sehingga akan tercipta pembelajaran yang aktif bagi siswa dan menyenangkan tanpa meninggalkan tujuan pembelajaran itu sendiri. Salah satu pendekatan dalam pembelajaran yang dapat digunakan dalam hal ini adalah pendekatan pembelajaran dengan menggunakan alat bantu berupa bok kardus dan gawang aman, yaitu suatu pendekatan pembelajaran untuk membantu siswa untuk mempelajari keterampilan dasar dalam mempelajari teknik dasar lompat jauh.

Model pembelajaran dengan pendekatan alat bantu dirancang dengan teliti agar bisa mengembangkan belajar siswa dan dilakukan dengan baik dan dapat dipelajari langkah demi langkah. Alat bantu berupa bok kardus dan gawang aman dalam pelaksanaan pembelajaran diharapkan membuat siswa lebih mudah menerima materi ajar, dan dapat mengubah suasana menjadi lebih rileks dan menyenangkan bahkan siswa saling berlomba memakai dan melewati alat bantu tersebut. Hal ini akan membantu meningkatkan motivasi siswa terhadap materi lompat jauh gaya jongkok. Adapun tujuan penelitian ini adalah untuk meningkatkan hasil belajar lompat jauh gaya jongkok melalui penggunaan media alat bantu Box bagi siswa di SD Negeri 38 Ampenan. 


\section{Metode Penelitian}

Metode penelitian ini menggunakan metode Penelitian tindakan kelas yang dilaksanakan di SD Negeri 38 Ampenan Kecamatan Sekarbela Kota Mataram. Subyek penelitian ini adalah siswa kelas V SD Negeri 38 Ampenan Kecamatan Sekarbela Kota Mataram. Seluruh siswa kelas V SD Negeri 38 Ampenan dijadikan subyek penelitian. Jumlah subyek dalam penelitian ini yaitu 15 orang siswa yang terdiri dari 10 siswa laki-laki dan 5 siswa perempuan. Siswa kelas V SD Negeri 38 Ampenan mayoritas berasal dari keluarga pegawai, oleh karena itu sebagian waktunya di rumah digunakan untuk bermain saja, sehingga mereka jarang melakukan latihan olahraga selama di rumah. Apalagi untuk materi lompat jauh, mereka, para siswa masih sangat asing, artinya mereka hanya akrab dengan olahraga permainan seperti sepak bola, sehingga materi lompat jauh seolah-olah dikesampingkan.

Data dan sumber data penelitian ini meliputi jenis data dan sumber data. Jenis data penelitian ini berupa motivasi belajar siswa dan kemampuan siswa dalam melakukan lompat jauh gaya jongkok. Sumber data yang digunakan dalam Penelitian Tindakan Kelas ini adalah sebagai berikut:

1) Siswa, sebagai subyek untuk mendapatkan data tentang lompat jauh gaya jongkok.

2) Guru, sebagai kolaborator, untuk melihat tingkat keberhasilan penerapan pembelajaran lompat jauh gaya jongkok dengan penggunaan alat bantu pada siswa kelas V SD Negeri 38 Ampenan Tahun Pelajaran 2017/2018.

3) Hasil tes formatif berupa data kuantitatif.

4) Hasil pengamatan keaktifan siswa berupa data kualitatif.

Data yang diperlukan dalam penelitian tindakan kelas ini berupa hasil wawancara dengan subyek penelitian yaitu siswa kelas $\mathrm{V}$ dan sumber data yaitu guru, dan pengumpulan catatan hasil pengamatan. Hasil pengamatan tersebut dikumpulkan melalui pengamatan, hasil tes siswa dan angket. Pemberian dan pengisian angket oleh siswa dilaksanakan pada pertemuan ke dua (siklus terakhir), setelah tindakan selesai. Data yang dianalisis meliputi data kuantitatif (dengan menampilkan angka-angka sebagai ukuran prestasi), dan data kualitatif (dengan menampilkan angka sebagai perbandingan). Analisis data dilakukan secara deskriptif komparatif yang bertujuan untuk membandingkan kondisi sebelum dan sesudah diadakan tindakan perbaikan pembelajaran. Tahapan dalam tindakan menganalisis data meliputi reduksi data, penyajian data, dan penarikan kesimpulan. Data kualitatif dianalisis dengan teknik analisis kritis, yaitu mengidentifikasi kelemahan dan kelebihan kinerja siswa dan guru selama proses penerapan tindakan. Hasil analisis tersebut menjadi bahan untuk menyusun rencana memperbaiki pelaksanaan tindakan pada siklus berikutnya.

Untuk menentukan ketercapaian tujuan, perlu dirumuskan indikator keberhasilan tindakan yang disusun secara realistik, yaitu mempertimbangkan kondisi pratindakan dan jumlah siklus tindakan yang akan dilakukan dan dapat diukur dengan jelas. Indikator kinerja penelitian ini dirumuskan sebagai berikut:

Tabel 1. Indikator Kinerja Penelitian

\begin{tabular}{|l|c|l|}
\hline Aspek yang Diukur & $\begin{array}{c}\text { Persentase Siswa } \\
\text { yang Ditargetkan }\end{array}$ & \multicolumn{1}{c|}{ Cara Mengukur } \\
\hline Minat belajar siswa & $80 \%$ & $\begin{array}{l}\text { Diamati saat pembelajaran dan dihitung } \\
\text { jumlah siswa yang memfokuskan } \\
\text { perhatiannya dalam melakukan lompat jauh } \\
\text { gaya jongkok. }\end{array}$ \\
\hline Keaktifan siswa dalam & $80 \%$ & Diamati saat pembelajaran dan dihitung \\
\hline
\end{tabular}




\begin{tabular}{|l|l|l|}
\hline $\begin{array}{l}\text { melakukan lompat jauh } \\
\text { gaya jongkok }\end{array}$ & $\begin{array}{l}\text { jumlah siswa yang menampakan keaktifan } \\
\text { dalam melakukan lompat jauh gaya } \\
\text { jongkok. }\end{array}$ \\
\hline $\begin{array}{l}\text { Keterampilan } \\
\text { melakukan lompat jauh } \\
\text { gaya jongkok }\end{array}$ & $75 \%$ & $\begin{array}{l}\text { Diukur dari hasil tes lompat jauh gaya } \\
\text { jongkok dan dihitung dari jumlah siswa } \\
\text { yang dapat melakukan lompat jauh gaya } \\
\text { jongkok. }\end{array}$ \\
\hline
\end{tabular}

\section{Hasil Penelitian dan Pembahasan Deskripsi Pratindakan}

Kegiatan pratindakan dilakukan sebelum pelaksanaan proses penelitian tindakan kelas berlangsung yang dimaksudkan untuk mengetahui keadaan sebenarnya tentang kondisi pembelajaran lompat jauh gaya jongkok siswa kelas V SD Negeri 38 Ampenan Kecamatan Sekarbela Kota Mataram yang berjumlah 15 siswa yang terdiri dari 10 siswa laki-laki dan 5 siswa perempuan.

Hasil belajar yang diperoleh pada kegiatan pratindakan pembelajaran lompat jauh gaya jongkok masih sangat rendah. Perhatian siswa tidak terfokus pada pembelajaran, terutama pada saat guru menyampaikan materi, hal itu disebabkan oleh karena guru belum menggunakan metode pembelajaran yang tepat dalam materi lompat jauh gaya jongkok. Informasi hasil wawancara menunjukkan bahwa siswa kesulitan dan kurang tertarik dalam menerima materi pembelajaran. Hal ini terbukti saat dilakukan pengamatan langsung di lapangan. Siswa terlihat acuh dan bermain sendiri ketika pembelajaran, bahkan ada beberapa siswa yang tetap asik berbicara dengan teman ketika guru menyampaikan materi. Sebagian siswa merasa takut dan canggung ketika guru memberikan materi, sehingga mereka kurang dapat memahami apa yang disampaikan oleh guru.

Tabel 2. Deskripsi Data Hasil Belajar Pratindakan

\begin{tabular}{|l|l|l|l|}
\hline No & Kriteria & Jumlah Anak & Prosentase \\
\hline 1. & Tuntas & 5 & $33,3 \%$ \\
\hline 2. & Belum tuntas & 10 & $66,7 \%$ \\
\hline JUMLAH & $\mathbf{1 5}$ & $\mathbf{1 0 0 \%}$ \\
\hline
\end{tabular}

Hasil penilaian pratindakan terhadap pembelajaran lompat jauh gaya jongkok siswa masih rendah, hanya 5 siswa $(33,3 \%)$ yang telah mampu melakukan lompat jauh gaya jongkok dengan benar. Melalui deskripsi data awal, masing-masing aspek menunjukkan kriteria keberhasilan pembelajaran yang kurang, maka disusun sebuah tindakan untuk meningkatkan hasil belajar lompat jauh gaya jongkok siswa kelas V SD Negeri 38 Ampenan dengan menggunakan alat bantu pembelajaran. Pelaksanaan tindakan dilakukan dengan 2 siklus, yaitu perencanaan, pelaksanaan tindakan, observasi, dan refleksi.

\section{Deskripsi Siklus I}

Pembelajaran lompat jauh gaya jongkok pada siklus I menggunakan alat bantu pembelajaran. Siswa mengikuti pembelajaran lompat jauh gaya jongkok dengan menggunakan alat bantu berupa bok kardus. Hasil penelitian siklus I sebagai berikut: 
Tabel 3. Deskripsi Data Hasil Belajar Siklus I

\begin{tabular}{|l|l|l|l|}
\hline No & Kriteria & Jumlah Anak & Prosentase \\
\hline 1. & Tuntas & 10 & $66,7 \%$ \\
\hline 2. & Belum tuntas & 5 & $33,3 \%$ \\
\hline JUMLAH & $\mathbf{1 5}$ & $\mathbf{1 0 0 \%}$ \\
\hline
\end{tabular}

Berdasarkan hasil deskripsi data siklus I, hasil lompat jauh gaya jongkok melalui alat bantu bok kardus siswa kelas V SD Negeri 38 Ampenan adalah sebanyak 10 siswa $(66,7 \%)$ telah mencapai KKM dan sisanya 5 siswa $(33,3 \%)$ belum mencapai KKM. Observasi/pengamatan penelitian dilakukan selama tindakan siklus I berlangsung, yaitu peneliti mengamati proses pembelajaran lompat jauh gaya jongkok melalui alat bantu bok kardus pada siswa kelas V SD Negeri 38 Ampenan Peneliti melakukan penilaian melalui lembar observasi siswa dengan tujuan untuk mengetahui tingkat keberhasilan belajar siswa dalam pembelajaran lompat jauh gaya jongkok melalui alat bantu bok kardus.

Berdasarkan hasil pengamatan terhadap proses pembelajaran diperoleh gambaran tentang hasil belajar siswa, yaitu sebanyak 10 siswa $(66,7 \%)$ telah mencapai KKM dan sisanya 5 siswa $(33,3 \%)$ belum mencapai KKM. Dalam melaksanakan tindakan siklus I terdapat kelebihan yang dapat digunakan sebagai tolok ukur keberhasilan pelaksanaan tindakan siklus I, yaitu bahwa siswa tidak merasa takut karena pembelajaran lompat jauh gaya jongkok melalui alat bantu bok kardus dapat dilakukan dengan mudah. Di samping kelebihan, pelaksanaan tindakan siklus satu juga terdapat kelemahan, yaitu masih banyak siswa yang belum dapat melakukan lompat jauh gaya jongkok melalui alat bantu bok kardus dengan benar, masih ada siswa yang bercanda dengan tutor sebaya karena mereka adalah teman, sehingga pembelajaran terganggu. Kesulitan yang dialami siswa dalam pembelajaran lompat jauh gaya jongkok melalui alat bantu bok kardus siklus I adalah pada saat siswa melakukan tolakan dan sikap badan di udara. Untuk mengatasi kesulitan tersebut, peneliti selalu memberikan contoh berulang kali kepada siswa, namun karena ada saja siswa yang tidak memperhatikan pembelajaran dan bermain sendiri sehingga pembelajaran kurang berhasil. Untuk mengatasi kesulitan di atas, peneliti merencanakan tindakan selanjutnya dengan menggunakan alat bantu yang berbeda agar siswa tidak merasa bosan, alat bantu tersebut adalah gawang aman.

\section{Deskripsi Siklus II}

Pembelajaran lompat jauh gaya jongkok pada siklus II merupakan tindakan lanjutan dari siklus I yang dirancang untuk memperbaiki hasil belajar dan kondisi pembelajaran siklus I. Pada siklus II ini siswa mengikuti pembelajaran lompat jauh gaya jongkok dengan menggunakan alat bantu berupa gawang aman. Pengambilan data dilakukan selama pelaksanaan tindakan siklus II. Deskripsi data yang diambil setelah tindakan siklus II disajikan dalam bentuk tabel sebagai berikut:

Tabel 4. Deskripsi Data Hasil Belajar Siklus II

\begin{tabular}{|l|l|l|l|}
\hline No & Kriteria & Jumlah Anak & Prosentase \\
\hline 1. & Tuntas & 15 & $100 \%$ \\
\hline 2. & Belum tuntas & 0 & $0 \%$ \\
\hline
\end{tabular}




\begin{tabular}{|l|l|l|}
\hline JUMLAH & 15 & $100 \%$ \\
\hline
\end{tabular}

Berdasarkan hasil deskripsi data siklus II, hasil lompat jauh gaya jongkok melalui alat bantu gawang aman siswa kelas V SD Negeri 38 Ampenan adalah seluruh siswa yang berjumlah 15 anak (100\%) telah mencapai KKM, sehingga pembelajaran siklus II ini dinyatakan telah berhasil. Pelaksanaan kegiatan pembelajaran lompat jauh gaya jongkok melalui alat bantu gawang aman berjalan lancar, suasana pembelajaran sangat kondusif dan siswa terlihat bersemangat. Proses pembelajaran, mulai dari pemanasan sampai dengan gerakan lompat jauh pada bak lompat diikuti siswa dengan sungguh-sungguh. Untuk mencatat segala aktifitas pembelajaran, peneliti menggunakan lembar observasi. Dari lembar observasi diperoleh data tentang keaktifan siswa dan keefektifan alat bantu gawang aman dalam pembelajaran lompat jauh gaya jongkok siswa kelas V SD Negeri 38 Ampenan. Penggunaan alat bantu gawang aman dalam pembelajaran lompat jauh gaya jongkok dapat meningkatkan keaktifan, motivasi, dan hasil belajar siswa pada siklus II.

Pembelajaran lompat jauh gaya jongkok melalui penggunaan alat bantu gawang aman telah berjalan sesuai dengan rencana yang dibuat. Alat bantu gawang aman yang digunakan oleh peneliti mampu menarik perhatian siswa, sehingga pembelajaran berlangsung secara maksimal. Hasil belajar siklus II telah menunjukkan peningkatan sesuai dengan apa yang ditargetkan, yaitu seluruh siswa yang berjumlah 15 anak (100\%) telah mencapai nilai KKM. Berdasarkan hasil tersebut disimpulkan bahwa hasil belajar lompat jauh gaya jongkok siswa melalui penggunaan alat bantu gawang aman telah mencapai kategori sangat baik. Kelebihan dan keberhasilan tindakan siklus II akan dipertahankan dan berupaya untuk meningkatkan. Untuk memperbaiki kelemahan dan kekurangan tindakan siklus II, antisipasinya adalah peneliti memberikan motivasi yang lebih dan melakukan pendekatan personal kepada siswa, agar tetap berkonsentrasi dan memperhatikan pembelajaran, sehingga tujuan dapat tercapai.

\section{Perbandingan Hasil Tindakan Antar Siklus}

Pelaksanaan tindakan perbaikan pembelajaran lompat jauh gaya jongkok dari pratindakan, siklus I, dan siklus II melalui penggunaan alat bantu gawang aman diketahui dari masingmasing tindakan telah mengalami peningkatan hasil belajar lompat jauh gaya jongkok siswa kelas V SD Negeri 38 Ampenan Kecamatan Sekarbela Kota Mataram. Selama proses pembelajaran siswa terlihat aktif dan antusias, sehingga pembelajaran berlangsung kondusif, sehingga hasil belajar sesuai dengan yang telah ditargetkan. Perbandingan hasil yang diperoleh selama proses tindakan dijabarkan dalam bentuk tabel sebagai berikut:

Tabel 5. Perbandingan Hasil Belajar Pratindakan, Siklus I, dan Siklus II

\begin{tabular}{|l|l|l|l|l|}
\hline No & \multicolumn{1}{|c|}{ Kriteria } & Pratindakan & Siklus I & Siklus II \\
\hline 1. & Tuntas & $33,3 \%$ & $66,7 \%$ & $100 \%$ \\
\hline 2. & Belum tuntas & $66,7 \%$ & $33,3 \%$ & $0 \%$ \\
\hline JUMLAH & $\mathbf{1 0 0 \%}$ & $\mathbf{1 0 0 \%}$ & $\mathbf{1 0 0 \%}$ \\
\hline
\end{tabular}

Data pada tabel diatas menunjukkan adanya peningkatan hasil belajar tiap siklusnya. Pada kegiatan pratindakan Persentase ketuntasan siswa baru mencapai 33,3\% saja, setelah dilakukan kegiatan siklus I hasil ketuntasan belajar siswa meningkat menjadi 66,7\%, kemudian pada kegiatan pembelajaran siklus II, seluruh siswa (100\%) telah tuntas belajar, ini menunjukkan bahwa penggunaan alat bantu gawang aman pada pembelajaran lompat jauh 
gaya jongkok dapat membantu meningkatkan keaktifan dan motivasi siswa sehingga hasil belajar meningkat dan mencapai tingkat ketuntasan yang diharapkan. Di samping hasil belajar, fokus dan keaktifan siswa juga meningkat, siswa terfokus pada pembelajaran, seluruh siswa juga telah aktif mengikuti pembelajaran, mereka terlihat antusias mengikuti pembelajaran.

\section{Pembahasan}

Pelaksanaan tindakan perbaikan pembelajaran melalui penelitian tindakan kelas pada materi lompat jauh gaya jongkok melalui penggunaan alat bantu bok kardus dan gawang aman telah dapat meningkatkan keaktifan dan semangat belajar siswa sehingga tujuan perbaikan tercapai dengan optimal. Penggunaan penggunaan alat bantu bok kardus dan gawang aman terbukti sangat membantu peningkatan hasil belajar siswa hal ini dikarenakan kelebihan penggunaan penggunaan alat bantu bok kardus dan gawang aman banyak memberikan keuntungan di antaranya siswa yang takut melakukan lompatan menjadi tidak takut. Siswa belajar dengan penuh percaya diri, semangat, disiplin, jujur, dan penuh tanggung jawab. Peningkatan hasil belajar siswa dapat dilihat dari tabel-tabel yang telah disajikan, yaitu pada pratindakan, siswa yang telah mencapai nilai KKM 5 anak $(33,3 \%)$ dan sisanya 10 anak belum mencapai nilai KKM. Pada siklus I siswa yang telah mencapai nilai KKM 10 anak $(66,7 \%)$ dan sisanya 5 anak belum mencapai nilai KKM. Pada siklus II seluruh siswa yang berjumlah 15 anak (100\%) telah mencapai nilai KKM. Dari pratindakan ke siklus I jika dibandingkan terlihat hasil belajar siswa mengalami kenaikan 5 anak (33,3\%), yaitu dari 5 siswa menjadi 10 siswa dan dari siklus I ke siklus II juga mengalami kenaikan 5 anak (33,3\%), yaitu dari 10 siswa menjadi 15 siswa.

\section{Kesimpulan}

Kesimpulan penelitian ini adalah pembelajaran lompat jauh gaya jongkok melalui penggunaan alat bantu dapat meningkatkan fokus dan keaktifan siswa serta suasana pembelajaran yang menyenangkan, sehingga pada akhirnya dapat meningkatkan hasil belajar siswa. Penelitian ini berimplikasi bagi perkembangan pembelajaran pendidikan jasmani dan olahraga kesehatan di SD Negeri 38 Ampenan. Guru pendidikan jasmani dan olahraga kesehatan dapat menerapkan pembelajaran atletik lompat jauh gaya jongkok melalui penggunaan alat bantu. Penggunaan alat bantu dapat pula digunakan pada materi pembelajaran pendidikan jasmani dan olahraga kesehatan lainnya, terutama pada cabang atletik, sehingga siswa merasa tertarik dengan pembelajaran yang menyenangkan sehingga tujuan akhirnya adalah dapat meningkatkan hasil belajar siswa.

\section{Saran}

Berdasarkan hasil penelitian yang telah dilakukan ada beberapa saran yang disampaikan yakni; (1) Bagi Sekolah; Sekolah hendaknya melengkapi seluruh alat bantu pembelajaran agar guru dapat menerapkan pembelajaran yang efektif, efisien, dan menyenangkan, sehingga siswa dapat belajar dengan fokus, aktif, dan antusias yang pada akhirnya tujuan pembelajaran dapat tercapai dengan maksimal. (2) Bagi Guru; Guru hendaknya dalam menyampaikan materi pembelajaran menggunakan alat bantu yang telah tersedia atau menyediakan alat bantu sendiri yang sesuai dengan materi pembelajaran, sehingga materi dapat disampaikan dengan mudah dan menyenangkan bagi siswa. (3) Bagi Siswa; hendaknya dapat mengikuti pembelajaran secara fokus, aktif, dan lebih serius, 
sehingga materi pembelajaran yang disampaikan oleh guru mudah diterima dan dikuasai, sehingga hasil belajar lebih meningkat.

\section{Daftar Pustaka}

Abu Ahmadi, Widodo Supriyono. (2004). Psikologi Belajar. Jakarta: Rineka Cipta.

Agus Kristiyanto. (2010). Penelitian Tindakan Kelas (PTK) Dalam Pendidikan Jasmani \& Kepelatihan Olahraga. Surakarta: UNS Press.

Apriyansyah, A., \& Baysha, M. (2019). PENGARUH MEDIA PEMBELAJARAN MATRIX LABORATORY (MATLAB) TERHADAP HASIL BELAJAR SISWA. Jurnal Teknologi Pendidikan, O(2), 10-20. Retrieved from http://ojs.ikipmataram.ac.id/index.php/jtp/article/view/1235

Dadang Heryana, Giri Verianti. (2010). Pendidikan Jasmani Olahraga dan Kesehatan untuk Siswa SD-MI Kelas V. Jakarta: Aneka Ilmu.

Depdiknas. (2003). Kurikulum 2004 Standar Kompetensi (Mata Pelajaran Pendidikan Jasmani Tingkat SD/MI. Jakarta: Depdiknas

Depdiknas. (2007). Naskah Akademik Pendidikan Jasmani Olahraga dan Kesehatan. Jakarta: BPP Pusat Kurikulum.

Djumindar, Mochamad. (2004). Gerakan-gerakan Dasar Atletik dalam Bermain. Jakarta: Grafindo Persada.

Hamalik, Oemar. (2004). Alat Pendidikan. Bandung: PT Aditya Bakti

Mardiana, dkk. (2010). Pendidikan Jasmani dan Olahraga. Jakarta: Aneka Ilmu

Nanang Sudrajat, dkk. (2005). Buku Penjas Orkes Kelas V. Bandung: PT. Sarana Panca Karya Nusa.

Patria, L., \& Djuniadi, D. (2015). Pengembangan Instrumen Penilaian Psikomotor Berbasis IT dalam Pembelajaran Penjasorkes Materi Lompat Jauh pada Siswa SMP. Jurnal Kependidikan: Jurnal Hasil Penelitian dan Kajian Kepustakaan di Bidang Pendidikan, Pengajaran dan Pembelajaran, 1(1). doi:https://doi.org/10.33394/jk.v1i1.398

Soekidjo. (2003). Alat Bantu Pembelajaran. Jakarta:

Sumantri M. Dan Syaodih, N (2006). Perkembangan Peserta Didik. Jakarta: Universitas Terbuka.

Tim Bina Kerja Guru. (2004). Pendidikan Jasmani untuk Sekolah Dasar Kelas 4. Jakarta: Erlangga.

Wina Sanjaya. (2006). Prinsip Pembelajaran. Jakarta: Rineka Cipta.

Zainuri, K. (2020). Peningkatan Hasil Pembelajaran Lompat Jauh Melalui Pendekatan Bermain Longu pada Siswa Kelas IV SDN 37 Ampenan. Jurnal Paedagogy, 7(1), 3542. doi:https://doi.org/10.33394/jp.v7i1.2513 